\title{
Materials for Literary Enjoyment Class
}

\author{
Julia Eka Rini \\ Sarah Prasasti
}

\begin{abstract}
As the introductory class of literature at the Faculty of Letters, Literary Enjoyment serves as a campaign to motivate students to appreciate and enjoy works of literature. Materials, which generally hinder the students' ability to enjoy literary works, should be carefully considered. Ideally, language and content should be easily digested but a compromise can be made between language and content.
\end{abstract}

Keywords: literary enjoyment, material, choice, language, content, literature, appreciate, enjoy, motivation, culture, literal, figurative.

For some Indonesian students, studying works of English literature is not enjoyable. As the subject for beginners in literature classes, literary enjoyment is crucial in determining whether students will be able to both enjoy and appreciate literature. Therefore, the teaching and learning process should be made successful in literary enjoyment classes. Several factors influencing the success of teaching literary enjoyment, according to Kemp (1985), are the learning conditions and principles that facilitate learning, such as pre-learning preparation, motivation, and learning objectives.

According to Kemp (1985), information about learners, such as their motivation and attitude toward the subject and their expectation or special talents in literature, for example, is important for the teachers. One way to assess this can be through questionnaires. As a tool in pre-learning preparation, a questionnaire can be distributed in the first week of the class so that teachers can have the necessary information about the students concerning the students' interest, expectation, special talent, basic knowledge and motivation before the class begins.

Motivation, for example, cannot be neglected due to its importance in every field of human learning, including studying literature. As Littlewood (1985) states:

Motivation is the crucial force which determines whether a learner embarks on a task at all, how much energy he devotes to it and how long he preserves. It is a complex phenomenon and includes many components: the individual's drive, need for achievement and success, curiosity, desire for stimulation and new experience, and so on. These factors play a role in every kind of learning situation.

Learning objectives are useful not only for students, but also for teachers. Learning objectives can be grouped into three major categories, namely cognitive, psychomotor and affective (Kemp, 1985, p. 189). The cognitive domain includes objectives concerning information or knowledge and thinking and other intellectual aspects of learning, while the affective domain involves objectives concerning attitudes, appreciation, values and emotion. For Literary Enjoyment the affective domain should precede the cognitive domain. In other words, enjoying, appreciating and creating beauty should be the main objective in studying literature. However, in formal teaching (in the classes at the 
Faculty of Letters) generally there are two factors limiting the affective domain from becoming the main concern of teaching literature. First, at the faculty level, Faculty of Letters generally adheres their program to the national curriculum. The objectives of the course taught should be the same with that mentioned in the national curriculum. Hence, the choice of materials should deeply consider the objective of the course. Second, at the student level there are academic requirements to be fulfilled because there is assessment of knowledge acquired by the students in class. Due to the two objectives of the two different domains, the teaching techniques, the approach and the material should be inherent with the objectives mentioned. However, this paper will only discuss the material because it is the material that causes students to have difficulties in both enjoying and appreciating literature.

The choice of materials for the Literary Enjoyment class involves these two aspects, the language and the content. A problem arises because the students who learn literary works use English as a second language. The language level of students is sometimes not high enough to deal with the works selected. That problem burdens both students and teachers. Teachers are expected to teach literature and language at the same time, while students spend a long time translating and working on detailed comprehension. Since students are still struggling with the language, they cannot enjoy, appreciate and value the beauty of the literature. Dealing with the content, students often have difficulties in understanding the culture, geographical facts and conditions described in the texts. Moreover, teachers may also be required to select works from the four main genres of literature such as poetry, novels, short story, and drama. Some students are not yet ready to deal with them due to their limited understanding of both the language and content of the literary works.

Nunan (1988) has suggested six principles for designing language-teaching materials that can be used in selecting materials for literary enjoyment class. The three principles most applicable to this discussion are first, materials should be clearly linked to the curriculum they serve. Second, materials should be authentic in terms of text. In deciding on text authenticity, the key question to ask is: "Were these materials specifically designed for the purposes of teaching or not? If they were not, it can be said that they are authentic" (p.4). Third, materials should stimulate interaction in class.

Based on the general requirement of the Faculty of Letters, the material should be in English. The implication is that any work of literature written in English regardless of the authors' nationalities can be used in Literary Enjoyment class. For example, at the Faculty of Letters at Petra, materials for Literary Enjoyment are taken not only from American and British authors but also from students' and teachers' writings, because the students are encouraged to write and explore their talents, for example in literature. In other words, besides American and British authors, Indonesian writers are also included. But unlike the authoritative American and British authors, these Indonesians are not authoritative writers. Still, their works are also authentic in the sense that their works are not specially designed for the language teaching. Besides, there are good Indonesian writers producing good literary works that have been translated into English.

Works of these authoritative Indonesian authors are moving closer to the so-called "real literature," for example, Sirikit Syah's works. There are, of course, arguments surrounding translated literary works concerning the quality of translation etc., but this will stimulate interaction in class, for example, Sirikit Syah's poem, "British 


\section{British Traditional Breakfast}

Sebutir telur diceplok

pilihan kentang, jamur, atau kacang merah

sosis atau bacon

secangkir kopi atau teh

lima belas pound

Sambil meneguk segelas jeruk,

dua ratus bungkus nasi pecel yang sedap

terbayang dalam ingatan

Lima belas poundsterling

Hampir sama dengan dua ratus ribu rupiah

Aku tersedak

sarapan dua ratus orang pengungsi

tengah aku kunyah-kunyah

mulutku terasa berdarah-darah

The translation, provided in the poetry reading circle held by The British Council, is as follows:

\section{British Traditional Breakfast}

One fried egg

Choices of potatoes, mushrooms or baked beans

Sausages or bacon

A cup of tea or coffee

Fifteen pounds

As I sip a glass of orange

I see two hundred packs of delicious, peanuty, breakfast rice

In my imagination

Fifteen pound sterling

Almost the same as two hundred thousand rupiah

I am choked

This is breakfast for two hundred refugees.

And as I chew

My mouth is full of blood

One example of a discussion that stimulates interaction that can be encouraged in class is about the translation of nasi pecel as peanuty breakfast rice. The students could argue whether the use of diction is correct or not.

Therefore, in terms of content, the choice of authoritative Indonesian authors will benefit the students of Literary Enjoyment. As they understand their own culture and the values of the society, they can grasp the content of the works more easily. By doing this they are sensitized to the topic and cultural background which might be a 
hindrance in understanding the works of western culture. Therefore, in terms of enjoyment, works of Indonesian translation into English can serve as a bridge before considering American and British works. Moreover, as the introductory class of literature, Literary Enjoyment class also gives the students a chance to taste some authoritative Indonesian literature.

Teachers should also feel free to expand the choice from the four main genres of literature to works such as speeches, letters, and humor. Such works use language that is not far removed from the ordinary mode of language since the words in those texts mean what they say. Yet, there are also works that employ figurative language. Martin Luther King's "I Have a Dream" as well as his other speeches and letters or the United States Declaration of Independence, for example, use words of that are not difficult, yet still employ ornamental and aesthetic touches of figurative language. In King's famous speech, he utilizes a variety of literary techniques. "Let us seek to satisfy our thirst for freedom by drinking from the cup of bitterness and hatred." King juxtaposes the black people's long time hope for equality as thirst; and metaphorically encourages a nonviolent movement. The repetition of the word "now" in "Now is the time to make real promises of democracy. Now is the time to rise from the dark and desolate valley...Now is the time to open the doors of opportunity..."(9) not only shows the literal intention that is the urgency of their demand, yet also employs a tremendous echoing effect of repetition. Hence, these kinds of texts serve as a bridge from the literal text to the figurative one. These kinds of texts will later help students to respond to works like short stories or poetry.

Literary Enjoyment, as the introductory literature class, gradually introduces students to the canonized works of literature. The selection of materials for this class should consider both language and content. Ideally both language and content should not be too difficult for students since the aim of this class is to help them enjoy and appreciate literature. However, sometimes this cannot be done. In that case, one of those two aspects, at least, should be put in priority. Either the content of the works should contain a familiar cultural background and general knowledge so that students can reach the aim of the course, or the language should be simpler yet still have literary values, although it may not belong to the four main genres. Hence, well-selected material of this class will encourage the students to appreciate works of literature.

\section{References}

Kemp, Jerrold E. (1985). The instructional design process. New York: Harper \& Row, Publishers, Inc.

Littlewood, William T. (1984). Foreign and second language learning. Cambridge: Cambridge University Press.

Nunan, David E. (1988). Principles for designing language teaching materials. Guidelines: A periodical for classroom language teachers 10, 2.

Sirikit Syah, "British Traditional Breakfast.” Poems presented at British Studies Circle Meeting and Poetry Reading at The British Council Surabaya, April 15, 2000. 
Workman, Marilyn. An American portfolio: Four very american days (American Holidays). "I Have a Dreamby Martin Luther King." United States Information Agency. 